\title{
Co-production of ecosystem services through agricultural practices: perception of stakeholders supporting smallholders in the Brazilian Amazon
}

\author{
Antonio Gabriel Lima Resque ${ }^{1, *}$, Marie-Gabrielle Piketty ${ }^{2,4}$, Emilie Coudel $^{2,4}$, Samir Messad ${ }^{3,5}$ and \\ Christophe Le Page ${ }^{2,4}$ \\ ${ }^{1}$ Universidade Federal Rural da Amazônia, Campus Paragominas, Paragominas, Brazil \\ 2 CIRAD, UMR SENS, 34398 Montpellier, France \\ 3 CIRAD, UMR SELMET, 34398 Montpellier, France \\ 4 SENS, Univ Montpellier, CIRAD, Montpellier, France \\ 5 SELMET, Univ Montpellier, CIRAD, INRAE, Institut Agro, Montpellier, France
}

\begin{abstract}
This paper investigates the perceptions of a diversity of stakeholders supporting smallholders in the eastern Brazilian Amazon about ecosystem services and agricultural practices. Our results come from 30 semi-structured interviews with key stakeholders in two contrasting municipalities in this region (Paragominas and Irituia). We identified 17 different ecosystem services and 15 agricultural practices. Using a multidimensional scaling (MDS), we differentiated the stakeholders' perceptions of co-production of ecosystem services. The most mentioned ecosystem services are food supply, regulation of water cycles, soil fertility and erosion prevention. Overall, there is a positive perception that agricultural practices are providing ecosystem services. Biodiversity-based practices are associated with the provision of a broad range of ecosystem services whereas mechanical-chemical practices are mainly linked to food supply. Use of fire, deforestation and use of chemical pesticides are perceived as having most negative effects on the provision of ecosystem services. The type of activity performed by the stakeholders and their municipality are the main factors influencing their perception of ecosystem services co-production. In conclusion, the concept of co-production of ecosystem services related to agroecosystems is relevant as local actors recognize a diversity of effects of agricultural practices on service provision.
\end{abstract}

Keywords: co-production of ecosystem services / agroecosystems / agricultural extension / low input agriculture / Multidimensional Scaling (MDS)

Résumé - Co-production de services écosystémiques par des pratiques agricoles : perception des acteurs en appui aux agriculteurs familiaux en Amazonie brésilienne. Cette étude analyse les perceptions relatives aux services écosystémiques et aux pratiques agricoles, de différents acteurs venant en appui aux agriculteurs familiaux en Amazonie brésilienne orientale. Nos résultats se fondent sur 30 entretiens semi-directifs avec des acteurs clés de deux municipalités contrastées de cette région (Paragominas et Irituia). Dix-sept services écosystémiques différents et 15 pratiques agricoles ont été identifiés. Un positionnement multidimensionnel (MDS) a permis de différencier la perception des acteurs sur la coproduction de services écosystémiques. La production de nourriture, la régulation des cycles de l'eau, la fertilité des sols et la prévention de l'érosion, sont les services écosystémiques les plus mentionnés. Globalement, les pratiques agricoles sont perçues de manière positive en termes de fourniture de services écosystémiques. Les pratiques basées sur la biodiversité (principalement l'introduction de différentes plantes) sont associées à une grande diversité de services, tandis que les pratiques basées sur les intrants chimiques et l'énergie mécanique sont principalement associées à la production de nourriture. L'utilisation du feu, la déforestation et l'utilisation des pesticides chimiques sont considérées comme ayant principalement des effets négatifs sur la fourniture de services écosystémiques. Le type d'activité exercée par les acteurs et la

\footnotetext{
*Corresponding author: gabriel.resque@ufra.edu.br
} 
municipalité sont les principaux facteurs influençant leur perception de la co-production de services écosystémiques. En conclusion, le concept de co-production lié aux agroécosystèmes est pertinent, car les acteurs locaux reconnaissent une diversité d'effets des pratiques agricoles sur la fourniture de services.

Mots clés : co-production de services écosystémiques / agroécosystème / vulgarisation agricole / agriculture faible niveau intrants / positionnement multidimensionnel (MDS)

\section{Introduction}

Agroecosystems are complex systems resulting from the interaction of ecological and human management processes (Tixier et al., 2013). These systems are currently one of the main drivers of degradation of ecosystems worldwide, contributing to and suffering from many of its consequences (MEA, 2005). Ecosystem services are the "outputs of ecosystems from which humans derive benefits directly or indirectly" (Lamarque et al., 2014). Ecosystem services are necessary to sustain agricultural productivity, but the conventional processes of managing agroecosystems that are designed to increase the production of goods (Dainese et al., 2019; Zhang et al., 2007) often degrade some of them (e.g. soil fertility, pollination). It thus becomes necessary to develop biodiversity-based agricultures, supported by intermediate ecosystem services (i.e. services that have a mediating function in generating goods), in order to face the challenge of maintaining or improving yields without compromising the integrity of agroecosystems (Duru and Therond, 2015).

Even though ecosystem services are frequently understood as "nature's free gifts to humans" (Haines-Young and Potschin, 2010 ), in most cases they are the result of a co-production process involving "socio-technical systems activating the potentials offered by nature's functions" (Spangenberg et al., 2014; Palomo et al., 2016). In this sense, ecosystem services are social constructions, since their recognition, mobilization and use depend on societal choices (Barnaud and Antona, 2014). This is especially the case with agroecosystems, in which most services are co-produced by humans and nature (Méral and Pesche, 2016).

The implementation of agricultural practices in agroecosystems depends on the availability of resources such as technology, inputs, labor or knowledge (Lamarque et al., 2014; Palomo et al., 2016). Different combinations of the use of natural resources and these anthropogenic resources determine the type of farming system (i.e. chemical input-, biological input- or biodiversity-based) (Therond et al., 2017), resulting in different impacts on productivity, workload and costs as well as on the delivery of a set of ecosystem services (Zhang et al., 2007). While farmers are the main actors responsible for land management decisions in agroecosystems, others stakeholders (e.g. policymakers, rural extension actors, unions, cooperatives, consumers) also influence their decision-making process, thus contributing indirectly to the co-production of ecosystem services (Tixier et al., 2013; Bennett et al., 2015). This contribution can take the form of specific interventions (e.g. supply of inputs, machines, technical advice; market access; rural credit) or of the establishment and implementation of formal and informal rules (e.g. norms, laws, policies) for farming activity (Duru and Therond, 2015).
The various stakeholders' perceptions of the different ecosystem services - and the values they accord to them depend on the local socio-ecological context (Díaz et al., 2006) and on subjective aspects such as knowledge, information, ideologic positioning and the expectations they have of these services (Lamarque et al., 2014; Teixeira et al., 2018). However, there is little knowledge on the perceptions the different stakeholders have of the co-production of the various ecosystem services and of their links to agricultural practices (Bennett et al., 2015; Bernués et al., 2016).

The purpose of this paper is to contribute to fill this gap, answering two specific questions in the eastern Brazilian Amazon: which services do different stakeholders supporting smallholders recognize? How do they relate ecosystem services and agricultural practices (co-production)? We assume that knowledge about these services and co-production processes is essential for people to take conscious decisions about the management of agroecosystems (Bennett et al., 2015; Lewan and Söderqvist, 2002). A better qualification of such knowledge can feed methodological tools aimed at improving communication between different actors, which is critical for fostering an on-ground agroecological transition (Dendoncker et al., 2018).

Discussing these elements is especially relevant in the Brazilian Amazon where a process of territorial and socioproductive reconfiguration in recent decades has resulted in the intensification of the conversion of ecosystems into agroecosystems through deforestation, with a strong negative impact on the provision of some important ecosystem services (Costa, 2008; Pokorny et al., 2013). With the emergence of environmental policies aimed at slowing down deforestation, smallholders are being incentivized to change their agricultural practices (Carneiro and Navegantes, 2019). It is therefore important to understand if and how stakeholders supporting these smallholders perceive ecosystem services and coproduction processes, as a first step in assessing their willingness to consider ecosystem services provision in governance and policy making (Spangenberg et al., 2014; Bennett et al., 2015).

\section{Material and methods}

\subsection{Context of the study}

The land use structure in the Brazilian Amazon is a complex arrangement of large-scale and smallholder farms with distinct rationalities and technological production patterns (Costa, 2008). Smallholders here usually produce more biodiverse landscapes based on ecosystem services, whereas larger units are usually more dependent on mechanical-chemical inputs (Pokorny et al., 2013). Two municipalities, Paragominas and Irituia, located in the eastern part of the 
Table 1. Entities and respondents (in brackets) interviewed in Paragominas (PGM) and Irituia (IRT). Columns correspond to the type of knowledge mobilized and rows to the entities' activities/sectors.

Tableau 1. Structures et répondants (entre parenthèses) interviewés à Paragominas (PGM) et Irituia (IRT). Les colonnes correspondent aux types de connaissances mobilisées et les lignes aux activités/secteurs des organismes.

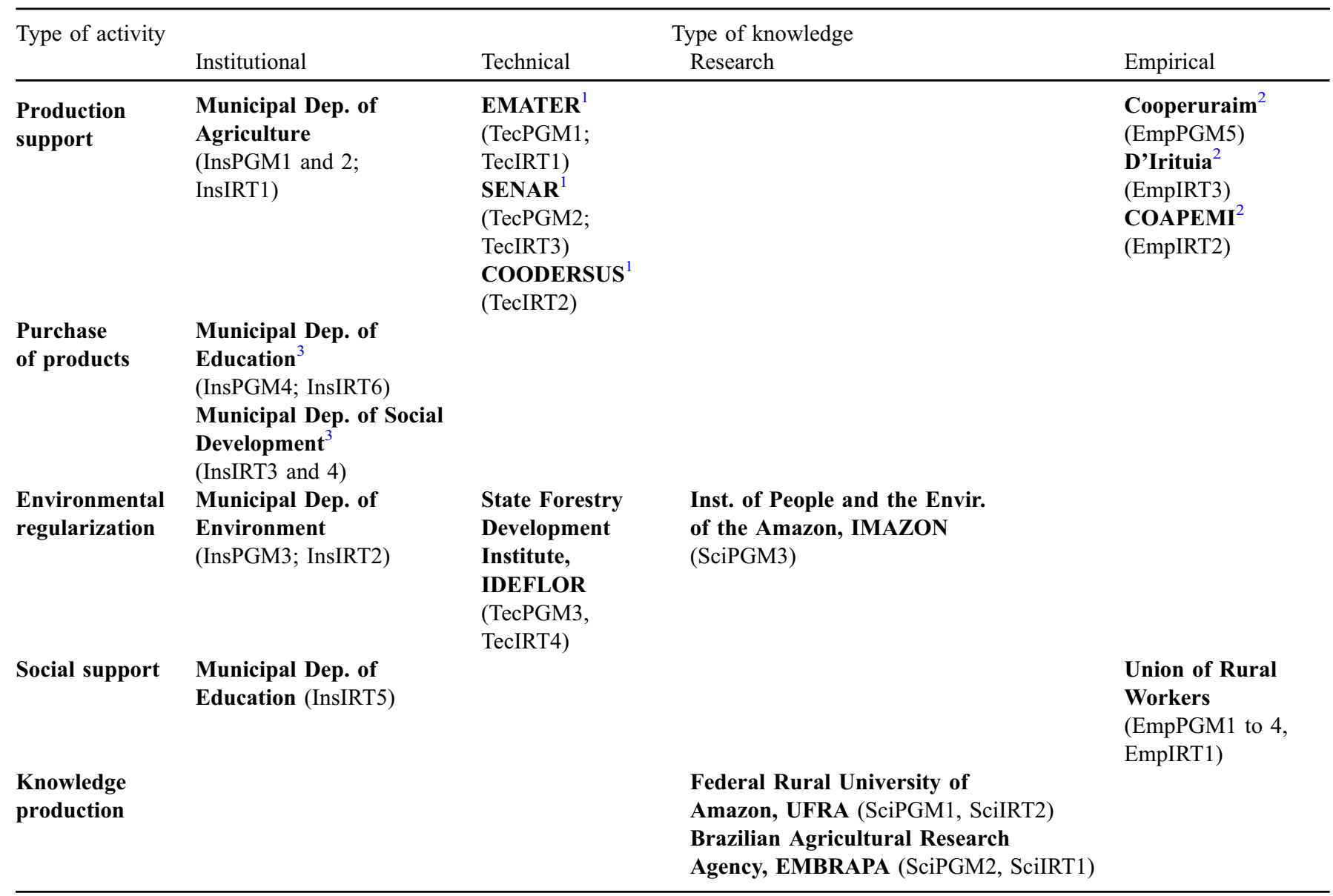

\footnotetext{
${ }^{1}$ Public/private rural extension entities.

${ }^{2}$ Family-farmer cooperatives.

${ }^{3}$ Representatives of food procurement programs.
}

Brazilian Amazon and representative of these two agricultural models, were selected for our empirical field research.

In Paragominas, industrial large-scale grain agriculture based on the use of chemical inputs and livestock is the predominant land use (Resque et al., 2019). Such farms coexist with rural communities and agrarian-reform areas that represent approximately $80 \%$ of the number of rural properties, but only $17 \%$ of the agricultural land (IBGE, 2017). Agriculture expansion has led to an intense process of deforestation in this municipality until 2012.

In Irituia, family farms predominate, representing $98 \%$ of all properties and $56 \%$ of the agricultural land (IBGE, 2017). Slash-and-burn practices, high population densities (i.e. 23.5 inhabitants $/ \mathrm{km}^{2}$ in Irituia and 5.8 inhabitants $/ \mathrm{km}^{2}$ in Paragominas in 2010, according to IBGE) and long-term colonization also drive deforestation in this municipality, but interesting processes of managing plant and animal diversity are also observed, mainly related to the cultivation of agroforestry systems (Carneiro and Navegantes, 2019).

\subsection{The stakeholders involved in the research}

Based on our knowledge of the study area, we conducted through purposive sampling a survey of the main entities supporting smallholders. Recognizing that ecosystem services are managed through interactions of multiple actors who may have differentiated perceptions of these services (Spangenberg et al., 2014; Bennett et al., 2015), we sampled respondents from entities with distinct types of knowledge and from different sectors, undertaking different activities in their role of providing support to farmers. As a result, we approached 24 entities, interviewing at least one key stakeholder per entity, for 30 interviewees, 15 in Paragominas and 15 in Irituia (Tab. 1).

Even recognizing different profiles and trajectories of each stakeholder, we considered that the type of knowledge they mobilize (e.g. scientific, empirical) is also related to the institution in which they are employed (Barreteau et al., 2010). Hence, in terms of the type of knowledge, entities were classified as: 
Table 2. Agricultural practices positively or negatively associated with ecosystem services. For optimal viewing, some practices are grouped. Color intensity indicates the frequency of citation of each practice.

Tableau 2. Pratiques agricoles associées positivement ou négativement aux services écosystémiques. Pour faciliter la visualisation, certaines pratiques ont été regroupées. Des niveaux de couleur soulignent l'intensité des citations de chaque pratique.

\begin{tabular}{|c|c|c|c|c|c|}
\hline \multirow[t]{2}{*}{ Practices (n) } & \multirow[t]{2}{*}{ Sub-practices (n) } & \multicolumn{2}{|c|}{$\begin{array}{c}\text { Positive } \\
\text { relations }\end{array}$} & \multicolumn{2}{|c|}{$\begin{array}{l}\text { Negative } \\
\text { relations }\end{array}$} \\
\hline & & Pgm & Irt & Pgm & Irt \\
\hline \multirow{5}{*}{$\begin{array}{c}\text { Biodiversity } \\
\text { management (276) }\end{array}$} & \multirow{5}{*}{$\begin{array}{l}\text { Forest maintenance } \\
\text { Riparian forest recovery } \\
\text { Introduction of plants } \\
\text { Introduction of animals } \\
\text { Genetic improvement }\end{array}$} & 36 & 16 & 0 & 0 \\
\hline & & 8 & 7 & 0 & 0 \\
\hline & & 68 & 100 & 3 & 3 \\
\hline & & 7 & 9 & 0 & 0 \\
\hline & & 2 & 5 & 1 & 0 \\
\hline Deforestation (37) & $\mathrm{N} / \mathrm{A}$ & 2 & 2 & 23 & 10 \\
\hline Use of fire (31) & N/A & 2 & 1 & 15 & 13 \\
\hline Mechanization (20) & $\mathrm{N} / \mathrm{A}$ & 9 & 10 & 1 & 0 \\
\hline Irrigation (11) & N/A & 8 & 2 & 1 & 0 \\
\hline \multirow{4}{*}{$\begin{array}{l}\text { Use of organic inputs } \\
\text { (34) }\end{array}$} & Fertilizers & 11 & 1 & 0 & 0 \\
\hline & Mulching & 5 & 8 & 0 & 1 \\
\hline & Pesticides & 2 & 1 & 0 & 0 \\
\hline & General & 2 & 3 & 0 & 0 \\
\hline \multirow{4}{*}{$\begin{array}{l}\text { Use of chemical } \\
\text { inputs }(55)\end{array}$} & \multirow{4}{*}{$\begin{array}{c}\text { Fertilizers } \\
\text { Pesticides } \\
\text { Transgenic seeds } \\
\text { General }\end{array}$} & 10 & 1 & 5 & 1 \\
\hline & & 2 & 2 & 12 & 8 \\
\hline & & 1 & 0 & 1 & 0 \\
\hline & & 6 & 2 & 2 & 2 \\
\hline
\end{tabular}

$n$ : number of citations.

- institutional: knowledge on proposals and implementation of public policies;

- technical: formal knowledge based mainly on technical information;

- scientific: academic knowledge structured and validated through scientific experimentation;

- empirical: knowledge based on empirical experience, not necessarily formalized (Barreteau et al., 2010).

Depending on the sector/activity, the type of support provided was classified as:

- production support: stakeholders directly associated with supporting food production;

- purchase of products: stakeholders responsible for the purchase of products;

- environmental regularization: stakeholders undertaking field activities on the environmental adequacy of farms;

- social support: stakeholders concerned with the social aspects of the farmer (access to rights, documentation, education);

- knowledge production: stakeholders involved in research and academic education (Resque et al., 2019).

\subsection{Data collection and analysis}

The semi-directive guide (Supplementary material 1) used for interviews with stakeholders was structured around personal and institutional issues, the relationship between biodiversity and agricultural practices, and the stakeholder's knowledge and perception of ecosystem services. The first author of this paper performed the data collection. The use of semi-directive interviews allowed the interviewees to present a broader view of their level of perception of the theme, and helped specify the different forms and terms associated with the perception of ecosystem services (Blanco et al., 2020). Questions about ecosystem services were intentionally placed at the end of the interview to explore if this concept emerged spontaneously during the interview or not.

All the interviews were recorded and transcribed, except one by objection of the respondent. In this case, detailed notes were taken. The language used for the interview was Portuguese. A glossary was later compiled with all mentions of ecosystem services in the interviews. These services were translated into English and divided into provisioning, supporting, regulating and cultural services (MEA, 2005). Then the number and the diversity of ecosystem services mentioned by each respondent were quantified. Multidimensional Scaling (MDS) was performed using R (R Core Team, 2020) to further explore variability in the stakeholders' perceptions. For these analyses, each stakeholder was considered as an observation and was characterized by the ecosystem services they cited as variables. The Monte Carlo test (Romesburg 1985) was also conducted to provide an overall indication of the differences between groups according to the three factors selected in our study: local context (municipality), type of knowledge, and type of activity.

Finally, we identified in the interviews which practices were associated positively (i.e. increase the expression of a service) or negatively (i.e. reduce or provide a low expression of a service) with the supply of ecosystem services. These practices were divided into 7 categories (Tab. 2). For optimal 


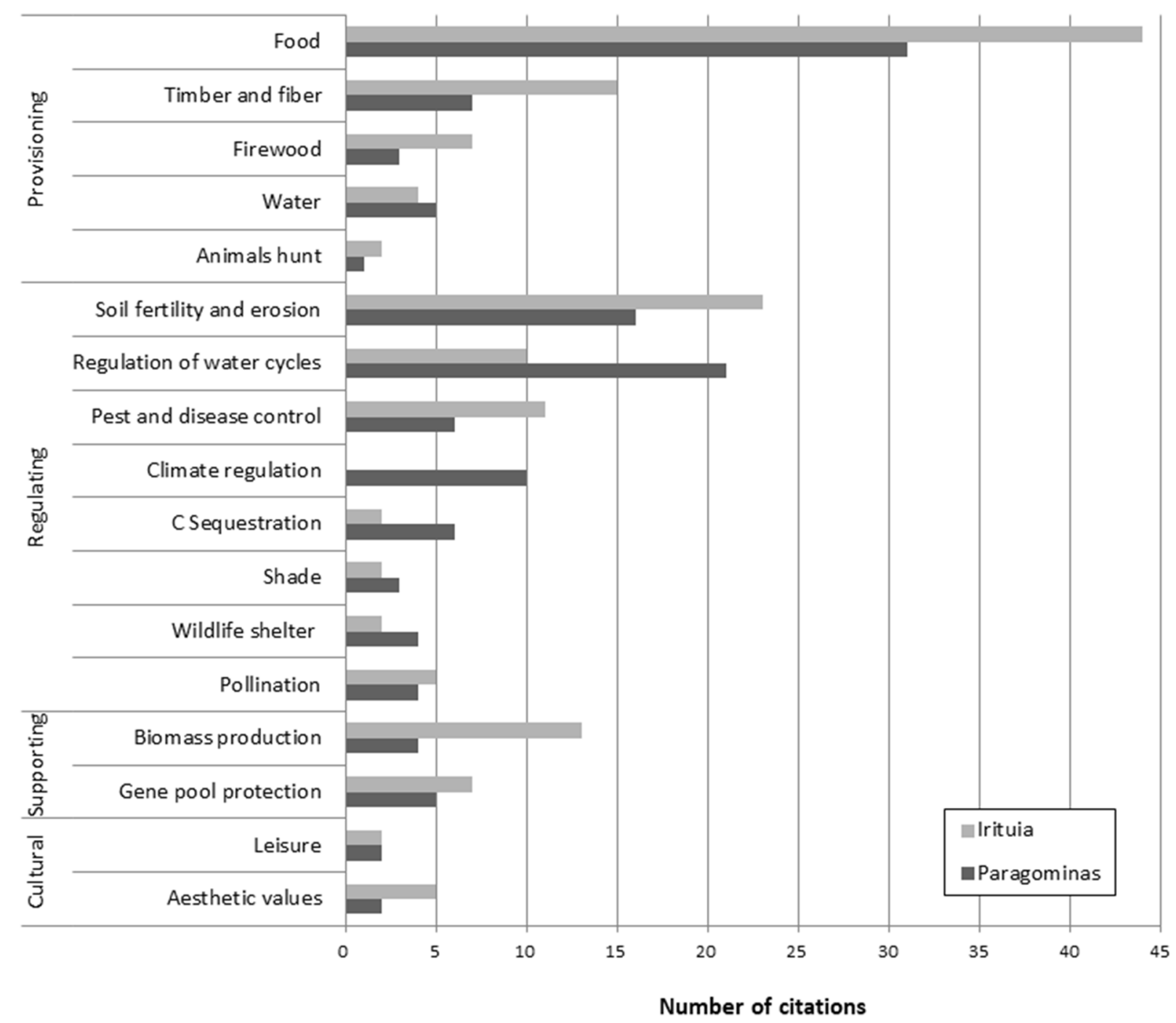

Fig. 1. Number of citations of different services by stakeholders. We consider the provisioning ecosystem services (e.g. food, timber/fiber, firewood) separately from biomass production, given their specific role in generating human welfare.

Fig. ?1. Nombre de citations des différents services par les acteurs. Nous avons considéré les services écosystémiques d'approvisionnement (e. g., nourriture, bois/fibre, bois de chauffage) séparément de la production de biomasse, étant donné leur rôle spécifique dans la génération du bien-être humain.

viewing, practices directly associated with biodiversity management (i.e. forest maintenance, riparian forest recovery, introduction of plant and animal species and genetic improvements), use of chemical inputs (i.e. use of fertilizers, pesticides and transgenic seeds) and use of organic inputs (i.e. fertilizers, mulching and pesticides) were grouped. Regarding "introduction of plants", we consider any vegetal species (e.g. crops, repellent plants, shadow plants, native, exotic) introduced in the agroecosystem. The other practices mentioned (i.e. deforestation, use of fire, mechanization, irrigation) were considered without grouping. These categories were used to draw a series of graphs to distinguish how stakeholders performing different activities perceive the relationship between agricultural practices and ecosystem services.

\section{Results}

\subsection{How do stakeholders supporting smallholder farmers perceive ecosystem services?}

\subsubsection{Ecosystem services perceived by stakeholders}

Forty-seven percent of the stakeholders in Paragominas and $60 \%$ of stakeholders in Irituia had never heard of ecosystem services or did not understand the concept of ecosystem services. The fact that they do not know the concept itself does not mean that they do not implicitly refer to some ecosystem services. Two hundred and eighty-five citations describing ecosystem services were collected from interviews, covering 17 ecosystem services types (Fig. 1). Negative effects of ecosystem processes on humans (i.e. disservices) were little 
mentioned and were not considered. The number of citations (Supplementary material 2) in Irituia (154 citations) was slightly higher than in Paragominas (131 citations). Some citations covered different services and were counted more than once. A diversity of perceptions and ways of mentioning services was observed.

Even though local actors mentioned provisioning services, especially food, more than other services (as was to be expected), they also mentioned a number of different regulating and supporting services. However, notable differences exist between Paragominas and Irituia in the actors' perception of these intermediate services. While local actors in Paragominas mentioned services linked to water maintenance (mainly regarding the risk of degradation of this service), those in Irituia were more aware of services linked to soil issues and pest and disease control. These services are normally related to supporting agriculture production. In Paragominas, however, some services not directly associated with agricultural productivity were also often highlighted, such as carbon sequestration and climate regulation. In both municipalities, cultural services were little mentioned.

\subsubsection{Differentiation between the stakeholders' perceptions}

The MDS results (Fig. 2A) revealed contrasting views between stakeholders. The horizontal axis distinguishes between the number and diversity of service citations by each actor and the vertical axis highlights the perception of the food supply service. According to the Monte Carlo test, the intergroup variance for location, activity and knowledge was respectively $0.065,0.185$ and 0.127 ; and for $P$-value respectively 0.017 , 0.042 and 0.120 . Hence, the activity variable demonstrated the highest intergroup variance, and activity and municipality were the most significant variables to distinguish stakeholders according to the diversity of services mentioned.

Comparing municipalities, Figure $2 \mathrm{~B}$ shows that the actors who mentioned a greater number and diversity of services are from Irituia. Irituia also presents greater disparity in perceptions of different services. Figure $2 \mathrm{~B}$ confirms that local actors in Irituia mention more the food supply service than in Paragominas.

As for the type of activity, Figure 2C shows that actors concerned with production support and knowledge production often mentioned a higher number and a greater diversity of services (right side of Fig. 2A). The former were predominant in the upper half of the figure (prevalence of mentions of food) and the latter were divided between the two sides. Among the actors who mentioned fewer services (left side of Fig. 2A) are mainly those responsible for the purchase of products (concentrated at the top) and social support (predominance at the bottom). Some actors linked to production support are found on the left side of Figure 2A; they are those who mainly favor an agro-industrial pattern of production. The actors responsible for environmental regularization were concentrated in an intermediate position of the horizontal axis at the bottom of Figure 2A (intermediate mentions of services, with little emphasis on food).

Regarding the type of knowledge, Figure 2D shows that there is less differentiation between groups according to this variable (also confirmed by the Monte Carlo test). However, this figure reveals disparity between actors with scientific knowledge (mentioning a higher number of services) and those with institutional knowledge (mentioning fewer services).

\subsection{How do stakeholders perceive ecosystem services and agricultural practices?}

Seven categories of agricultural practices were identified as positively or negatively affecting ecosystem services provision (Tab. 2). There is an overall perception that agricultural practices have positive effects on ecosystem services (i.e. $77 \%$ of the total mentions), with a few exceptions for practices that were predominantly considered as negative (i.e. use of fire, deforestation and use of pesticides). Some practices have been mentioned as having both positive and negative effects on a same service (e.g. positive short-term and negative long-term effect on services such as food supply or soil fertility) or on different services (e.g. an increase in food production at the cost of contamination of water courses). To a lesser extent, these differences reflected differing opinions among actors.

We constructed five separate graphs (Fig. 3) grouping actors according to their type of activity to further explore correlations between ecosystem services and agricultural practices presented in Table 2 . The positive effects of practices on services present different patterns. Some mechanicalchemical practices (i.e. use of chemical inputs, mechanization, irrigation) were mainly associated with food supply whereas biodiversity-based practices (i.e. biodiversity management, use of organic inputs) were associated with a broader diversity of services. Negative effects of practices were predominantly associated with biodiversity/nature (terms used by the interviewees), water regulation and food quality (Fig. 3). Few contradictions were observed in the statements made by the different stakeholders about how a particular agricultural practice affects the provision of a given service (Supplementary material 3). However, according to their activity, stakeholders mentioned different practices and correlations with services.

\subsubsection{Production support}

Interviewees from this group mentioned a combination of practices, pertaining, for the most part, to food provisioning. Intermediate services mainly concerned biodiversity management and organic practices (e.g. mulching, manure). The negative effect of some practices (e.g. chemical inputs; fire) was also mentioned, mainly linked to biodiversity and food quality.

\subsubsection{Purchase of products}

These stakeholders mentioned very few practices, focusing on biodiversity management for the provision of food and organic practices (e.g. manure, use of natural pesticides) for food quality. They associated almost no practice with other services, except the negative effects of chemical inputs on food quality. 


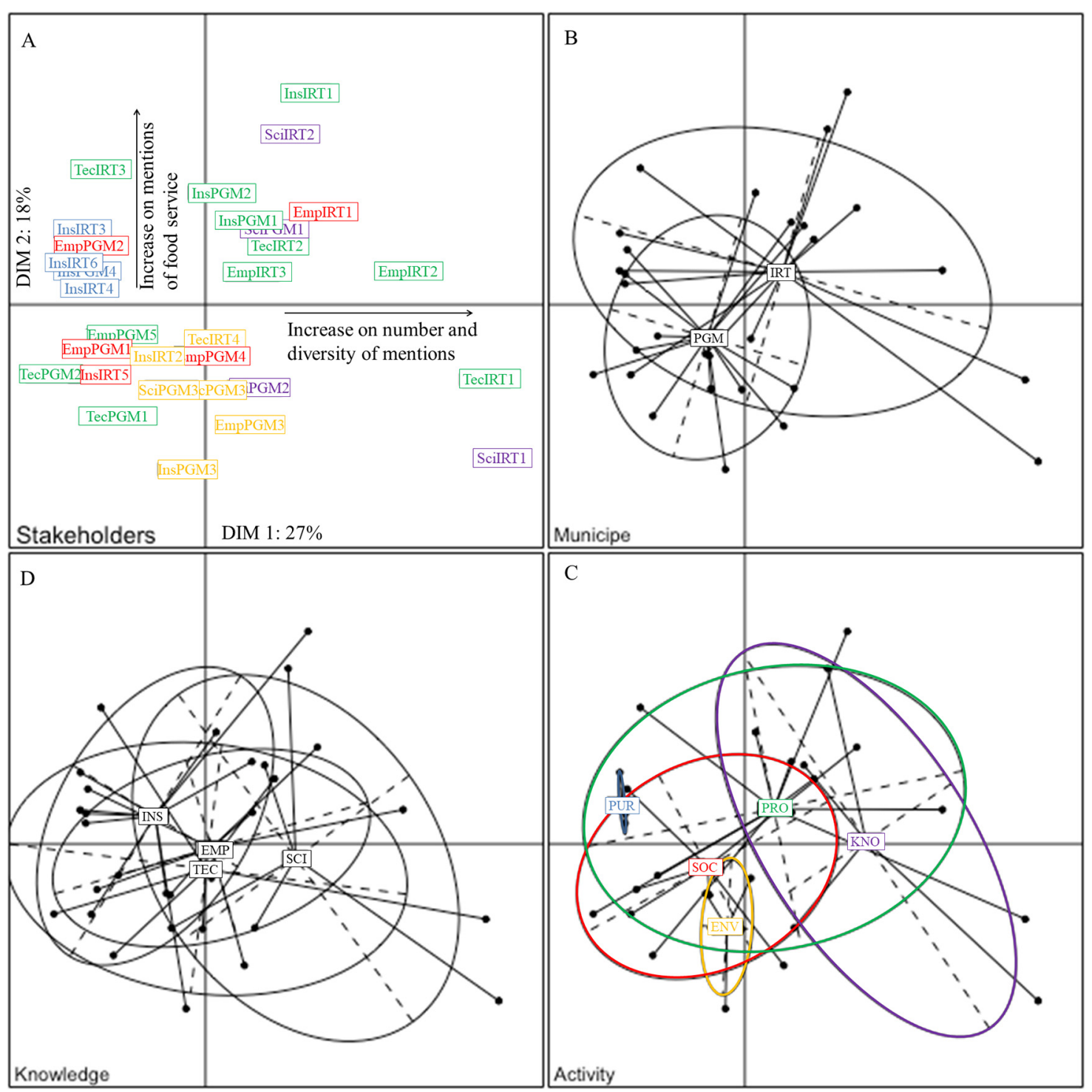

Fig. 2. Multidimensional Scaling (MDS) outcomes. (A) Projections on the two first MDS axes of the stakeholders. (B-D) Variability of stakeholder responses according to: location (Paragominas, PGM; Irituia, IRT), activity (production support, PRO; purchase of products, PUR; environmental regularization, ENV; social support, SOC; knowledge production, KNO) and knowledge type (institutional, INS; technical, TEC; scientific, SCI; empirical, EMP). The label of each factor's modality appears at the average MDS coordinates of the stakeholders who belong to the modality concerned. An inertia ellipse containing $95 \%$ of the points is shown to illustrate the variability of the distribution of ecosystem services perception by stakeholders within each modality.

Fig. 2. Résultats du MDS. (A) Projections sur les deux premiers axes du MDS des acteurs. $(B-D)$ Variabilité des réponses des acteurs en fonction de la municipalité (Paragominas, PGM; Irituia, IRT), l'activité (soutien à la production, PRO; achat de produits, PUR; réglementation environnementale, ENV; soutien social, SOC; production de connaissance, KNO) et type de connaissance (institutionnel, INS; technique, $T E C$; scientifique, SCI ; empirique, EMP). La position du label de la modalité de chaque facteur correspond à la moyenne des coordonnées MDS des acteurs qui appartiennent à la modalité concernée. Une ellipse d'inertie contenant $95 \%$ des points est présentée pour illustrer la variabilité de la distribution de la perception des services écosystémiques par les acteurs au sein de chaque modalité.

\subsubsection{Environmental regularization}

In contrast to the other groups, there was no focus on food supply, cited in similar numbers to timber/fiber supply and intermediate services related to soil and water issues. In this group, a major role was attributed to practices related to biodiversity management. Some negative effects of practices were mentioned, mainly related to the impact of fire use and deforestation on biodiversity.

\subsubsection{Social support}

This group was unusual in its high number of mentions of negative effects, as opposed to positive ones, of agricultural practices on services. They mainly concerned the impacts of fire use and deforestation on biodiversity and on water regulation (mainly deforestation). Positive effects of practices primarily pertained to biodiversity-based practices, especially to supply of food. 


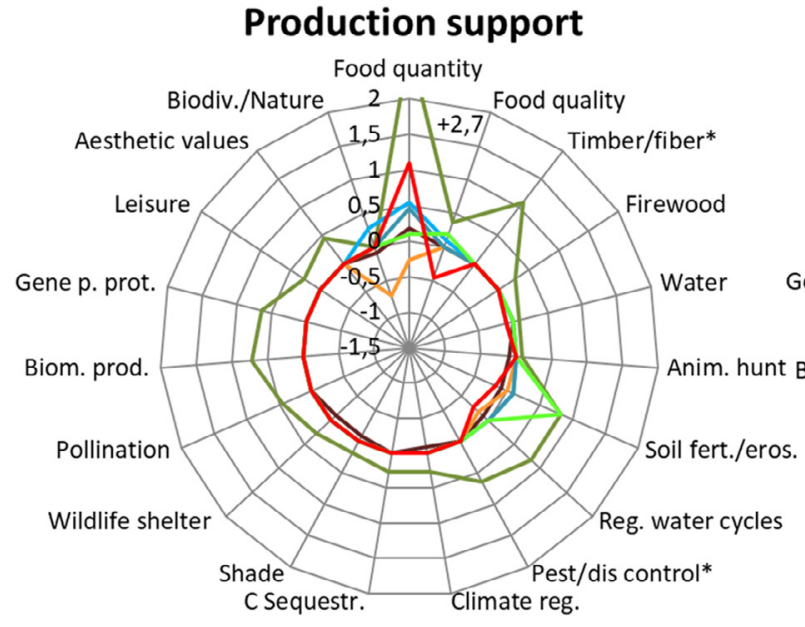

Environmental regularization

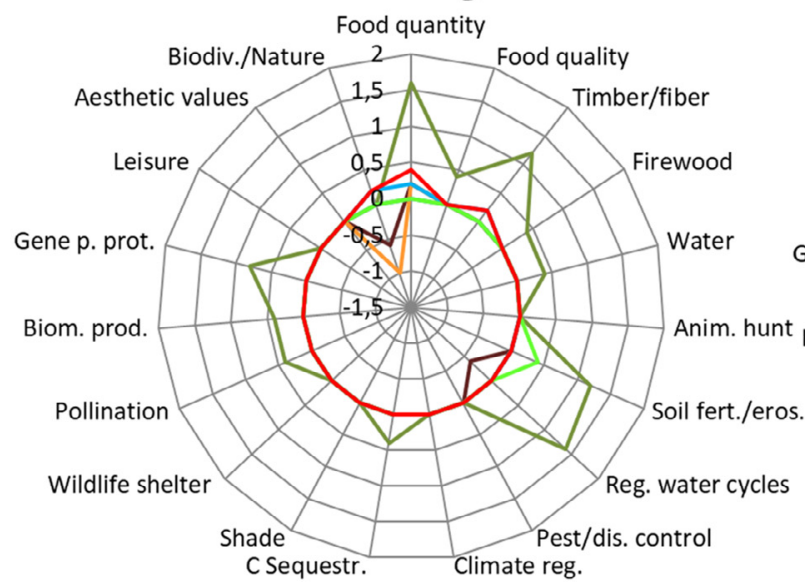

\section{Social support}

Food quantity

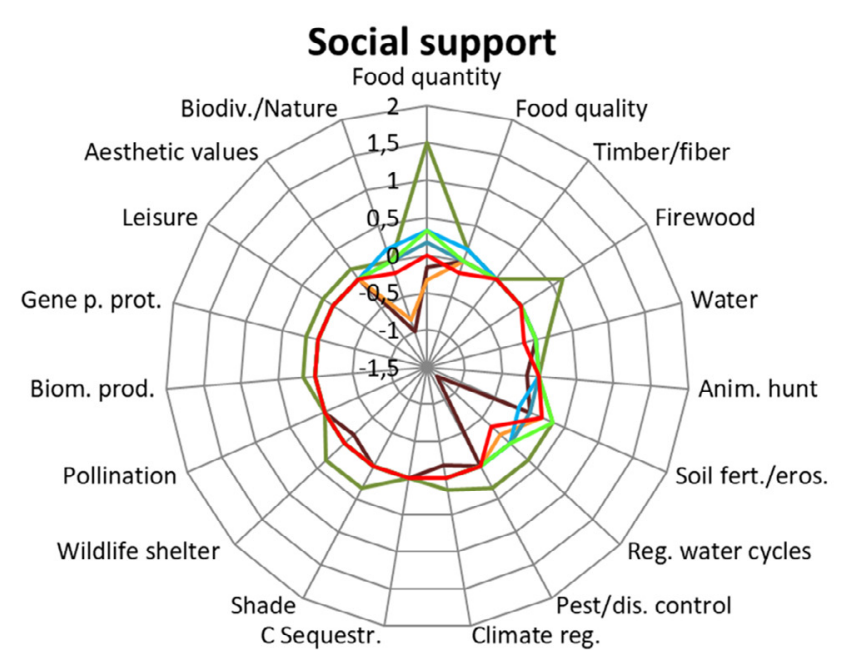

Purchase of products

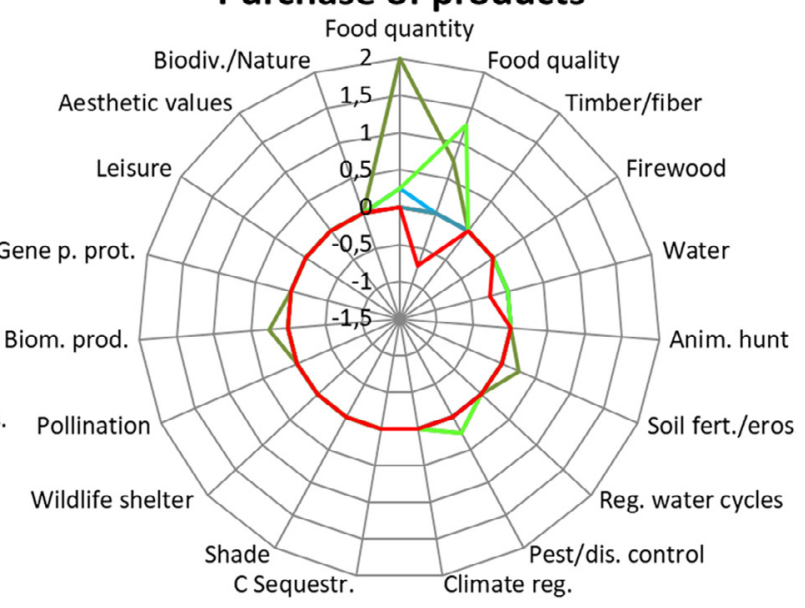

Knowledge production

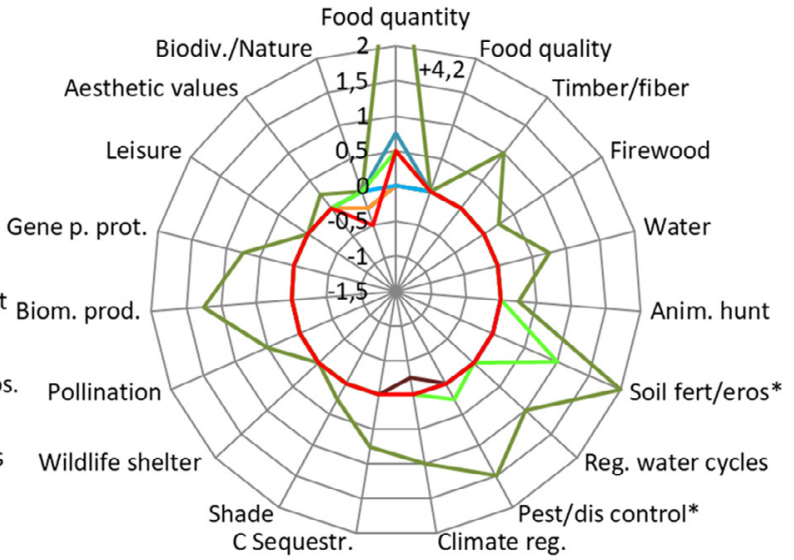

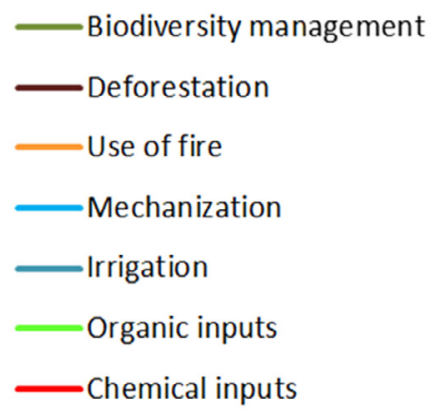

Fig. 3. Stakeholder perception of the relationships between agricultural practices and ecosystem services. The positive or negative values indicate positive or negative relationships respectively. For services associated both positively and negatively with a same practice, the difference in the number of mentions was considered. Biodiversity/nature and food quality were included here as services as some practices were mentioned as directly affecting them. Since the groups are of different sizes, the average number of mentions made by respondents in each group was used. *Cases in which only one or two respondents mentioned the particular service.

Fig. ?3. Perception par les acteurs de la relation entre pratiques agricoles et services écosystémiques. Les valeurs positives ou négatives indiquent respectivement des relations positives ou négatives. Pour les services associés positivement et négativement à une même pratique, nous utilisons la différence entre le nombre de mentions. La biodiversitélla nature et la qualité des aliments ont été incluses ici comme services car certaines pratiques ont été mentionnées comme les affectant directement. Nous utilisons le nombre moyen de mentions dans chaque groupe. * Cas dont les mentions ont été faites seulement par un ou deux répondants. 


\subsubsection{Knowledge production}

References to organic and biodiversity management practices were widespread in this group, predominantly linked to food supply, but also to other final and intermediate services. Few mentions of mechanical-chemical practices (mainly associated with food supply) and of negative effects of practices.

\section{Discussion}

\subsection{Perception of ecosystem services}

First, our results demonstrate that the difference in perception of ecosystem services is not directly linked to the type of knowledge of the stakeholders (Fig. 2D). Previous studies have suggested this influence (Altieri, 2004), but our analysis was not qualitative enough to confirm this (i.e. mentions of highly scientific or empirical observation of services). The type of activity (Fig. 2C) undertaken by each stakeholder has more influence on the services perceived. Stakeholders with activities directly linked to food production and purchase, for example, are predictably more concerned by this provisioning service. Stakeholders involved in production are aware of other ecosystem services, notably those that support agricultural production. Investigating these perceptions is essential to help us understand the key services that are likely to be co-produced at each location, as these perceptions are an indicator of the benefits (and beneficiaries) that are recognized locally (Bennett et al., 2015; Spangenberg et al., 2014).

Different perceptions of ecosystem services are also observed when comparing the two municipalities (Fig. 2B). In line with Díaz et al. (2006) and Haines-Young and Potschin (2010), this finding confirms that contextual aspects represent a major source of differentiation in perception of ecosystem services. These differences can arise from the strategic ecosystem services relevant to agricultural production in each municipality (either by the satisfactory provision of this service, or by limitations in its provision) or as a consequence of the predominant production pattern in the municipality (see Resque et al. (2019) for further elements). For example, in Paragominas, the negative effects of deforestation on the regulation of water cycles were widely mentioned, as it has led to increased droughts and floodings. In Irituia, most services mentioned related to the soil (i.e. soil fertility/erosion and biomass production) and highlighted the practices implemented to improve the conditions of these soils (e.g. mulching, manure use).

\subsection{Perceptions of co-production of ecosystem services in agroecosystems}

Biodiversity management practices (e.g. maintenance of forestry spaces, introduction of plants) were recognized by all categories of stakeholders as provisioning a large number of ecosystem services. Negative effects of agricultural practices, such as the use of fire and deforestation, have been reported by almost all groups as affecting biodiversity, which consequently jeopardizes the provision of diverse ecosystem services associated with biodiversity. A number of practices (e.g. mechanization, irrigation, use of chemical inputs) were also mentioned, primarily associated with food production. Regarding chemical inputs, trade-offs were acknowledged between food provision and other services. To a less extent, trade-offs were also associated to the other practices.

The perception of how agricultural practices and ecosystem services are linked also depends on the activity of the stakeholder. Actors related to food production mentioned mechanical and chemical practices more often (when compared to others) as a means of increasing the production of these goods, while those responsible for purchasing food focused on practices associated with biodiversity (more healthy). The latter actors also highlighted the negative impact of the use of chemicals on the quality of products. Actors linked to environmental regularization focused on practices benefiting the provision of ecosystem services, and those linked to social support reported the negative effects of practices for the provision of these ecosystem services. The positive and negative effects of the use of agrochemicals were more mentioned in Paragominas than in Irituia. Existing research has also shown that agricultural principles (i.e. agroecological, organic or conventional) influence this perception (Teixeira et al., 2018; Blanco et al., 2020). Reconciling (or not) these different visions in order to supply ecosystem services critically depends on how governance arenas and power relations are configured locally (Spangenberg et al., 2014).

Our results demonstrated that most services are indeed perceived as being co-produced (or degraded) by active human intervention according to their resources (e.g. seeds, workforce, knowledge, machinery, chemical inputs). This can help assess the "inputs" necessary to improve (or which may compromise) the provision of ecosystem services (Palomo et al., 2016). Even services that are associated with the maintenance of forestry spaces, which can be considered as being "naturally generated", can be understood as a human-driven form of improving the provision of services (as discussed in Barnaud and Antona, 2014, p. 116) since the maintenance of these areas depends on societal motivation (e.g. compliance with environmental legislation, personal consciousness).

Stakeholders have to understand this set of relations before they can consciously change their attitudes towards ecosystem management (Lewan and Söderqvist 2002). However, a diversity of well-established correlations in literature (e.g. use of organic alternatives to reduce pest and diseases or negative impacts of irrigation on water supply) was rarely mentioned by the interviewees. This suggests a limited understanding by some stakeholders of certain ecosystem services, which, as noted by previous studies, may hinder the development of land use interventions for the sustainable delivery of multiple ecosystem services (Lamarque et al., 2014; Spangenberg et al., 2014).

\section{Conclusion}

In the context of both municipalities, a set of ecosystem services were listed as important for the functioning of agroecosystems, whether for the provision of goods or for intermediate services related to this provision. Furthermore, ecosystem services provision was mostly perceived as being 
positively induced by agricultural practices, especially by biodiversity-based practices. Thus, the concept of co-production is relevant since stakeholders, even if not exhaustively, recognize a diversity of effects of agricultural practices on ecosystem services provision. The type of activity undertaken by stakeholders and the local context proved to be important variables in differentiating these perceptions. Since cognitive elements are one of the factors in decision-making processes for managing agroecosystems in ways that can promote biodiversity and ecosystem services, further studies are necessary to investigate how such processes can be effectively implemented with farmers. A coordination process that engages these stakeholders between themselves and with farmers could be a promising approach to strengthen biodiversity-based practices in the Brazilian Amazon.

\section{Supplementary Material}

SM1 - Semi-directive guide

SM2 - Mentions of ecosystem services

SM3 - Relation between AP and ES (individual stakeholder)

The Supplementary Material is available at https:/www. cahiersagricultures.fr//10.1051/cagri/2021006/olm.

\section{References}

Altieri MA. 2004. Linking ecologists and traditional farmers in the search for sustainable agriculture. Frontiers in Ecology and the Environment 2: 35-42. https://doi.org/10.1890/1540-9295(2004) 002[0035:LEATFI]2.0.CO;2.

Barnaud C, Antona M. 2014. Deconstructing ecosystem services: uncertainties and controversies around a socially constructed concept. Geoforum 56: 113-123. https://doi.org/10.1016/j.geo forum.2014.07.003.

Barreteau O, Bousquet F, Etienne M, Souchère V, D'Aquino P. 2010. La modélisation d'accompagnement: une méthode de recherche participative et adaptative. In: La modélisation d'accompagnement: une démarche en appui au développement durable. Paris (France): Quae éditions, pp. 21-46.

Bennett EM, Cramer W, Begossi A, Cundil G, Díaz S, Egoh B, et al. 2015. Linking biodiversity, ecosystem services, and human wellbeing: three challenges for designing research for sustainability. Current Opinion in Environmental Sustainability 14: 76-85. https://doi.org/10.1016/j.cosust.2015.03.007.

Bernués A, Tello-García E, Rodríguez-Ortega T, Ripoll-Bosch R, Casasús I. 2016. Agricultural practices, ecosystem services and sustainability in High Nature Value farmland: unraveling the perceptions of farmers and nonfarmers. Land Use Policy 59: 130142. https://doi.org/10.1016/j.landusepol.2016.08.033.

Blanco J, Sourdril A, Deconchat M, Barnaud C, Cristobal M, Andrieu M. 2020. How farmers feel about trees: perceptions of ecosystem services and disservices associated with rural forests in southwestern France. Ecosystem Services 42: 101066. https://doi.org/ 10.1016/j.ecoser.2020.101066.

Carneiro R, Navegantes L. 2019. A diversidade de experiências de recuperação florestal praticada por agricultores familiares do Nordeste do Pará. Geoambiente On-line: 293-314. https://doi.org/ 10.5216/revgeoamb.v0i35.57152.

Costa F. 2008. Desenvolvimento sustentável na Amazônia: o papel estratégico do campesinato. In: $\mathrm{O}$ desafio da sustentabilidade: um debate socioambiental no Brasil. São Paulo (Brazil): Fundação Perseu Abramo, pp. 289-313.

Dainese M, Martin EA, Aizen MA, Albrecht M, Bartomeus I, Bommarco R. 2019. A global synthesis reveals biodiversity-mediated benefits for crop production. Science Advances 5: eaax0121. https://doi.org/ 10.1126/sciadv.aax0121.

Dendoncker N, Boeraeve F, Crouzat E, Dufrêne M, König A, Barnaud C. 2018. How can integrated valuation of ecosystem services help understanding and steering agroecological transitions? Ecology and Society 23(1): 12. https://doi.org/10.5751/ ES-09843-230112.

Díaz S, Fargione J, Chapin III FS, Tilman D. 2006. Biodiversity loss threatens human well-being. PLoS Biology 4: e277. https://doi.org/ 10.1371/journal.pbio.0040277.

Duru M, Therond O. 2015. Designing agroecological transitions: a review. Agronomy for Sustainable Development 35: 1237-1257. https://doi.org/10.1007/s13593-015-0318-x.

Haines-Young R, Potschin M. 2010. The links between biodiversity, ecosystem services and human well-being. In: Raffaelli CLJ, Frid DG, eds. Ecosystem ecology: a new synthesis. Cambridge (United Kingdom): Cambridge University Press, pp. 110-139. https://doi. org/10.1017/CBO9780511750458.007.

IBGE - Censo Agropecuário. 2017. [2019/11/18]. https://censos. ibge.gov.br/agro/2017.

Lamarque P, Meyfroidt P, Nettier B, Lavorel S. 2014. How ecosystem services knowledge and values influence farmers' decisionmaking. PLoS One 9: e107572. https://doi.org/10.1371/journal. pone. 0107572

Lewan L, Söderqvist T. 2002. Knowledge and recognition of ecosystem services among the general public in a drainage basin in Scania, Southern Sweden. Ecological Economics 42: 459-467. https://doi.org/10.1016/S0921-8009(02)00127-1.

MEA. 2005. Ecosystems and human well-being, 1st ed. Washington: Island press, $64 \mathrm{p}$.

Méral P, Pesche D. 2016. Les services écosystémiques. Repenser les relations nature et société, $1^{\mathrm{er}}$ ed. Versailles: Éditions Quae, $300 \mathrm{p}$. https://doi.org/10.35690/978-2-7592-2470-8.

Palomo I, Felipe-Lucia MR, Bennett EM, Martín-López B, Pascual U. 2016. Disentangling the pathways and effects of ecosystem service co-production. Advances in Ecological Research 54: 245-283. https://doi.org/10.1016/bs.aecr.2015.09.003.

Pokorny B, de Jong W, Godar J, Pacheco P, Johnson J. 2013. From large to small: reorienting rural development policies in response to climate change, food security and poverty. Forest Policy and Economics 36: 52-59. https://doi.org/10.1016/j.for pol.2013.02.009.

R Core Team. 2020. R: a language and environment for statistical computing. Vienna, Austria: R Foundation for Statistical Computing. https://www.R-project.org/.

Resque G, Coudel E, Piketty MG, Cialdella N, Sá T, Piraux M, et al. 2019. Agrobiodiversity and public food procurement programs in Brazil: influence of local stakeholders in configuring green mediated markets. Sustainability 11: 1425. https://doi.org/ $10.3390 /$ su11051425.

Romesburg HC. 1985. Exploring, confirming, and randomization tests. Computers \& Geosciences 11: 19-37. https://doi.org/ 10.1016/0098-3004(85)90036-6.

Spangenberg JH, Görg C, Truong DT, Tekkene V, Bustamantef K, Setteleg J. 2014. Provision of ecosystem services is determined by human agency, not ecosystem functions. Four case studies. International Journal of Biodiversity Science, Ecosystem Services \& Management 10: 40-53. https://doi.org/10.1080/ 21513732.2014.884166. 
Teixeira HM, Vermue AJ, Cardoso IM, Claros M, Bianchia F. 2018. Farmers show complex and contrasting perceptions on ecosystem services and their management. Ecosystem Services 33: 44-58. https://doi.org/10.1016/j.ecoser.2018.08.006.

Therond O, Duru M, Roger-Estrade J, Richard G. 2017. A new analytical framework of farming system and agriculture model diversities. A review. Agronomy for Sustainaible Development 37: 21. https://doi.org/10.1007/s13593-017-0429-7.
Tixier P, Peyrard N, Aubertot JN, Gaba S, Radoszycki J, Caron-Lormier G. 2013. Modelling interaction networks for enhanced ecosystem services in agroecosystems. Advances in Ecological Research 49: 437-480. https://doi.org/10.1016/B978-0-12-420002-9.00007-X.

Zhang W, Ricketts TH, Kremen C, Carney K, Swinton S. 2007. Ecosystem services and dis-services to agriculture. Ecological Economics 64(2): 253-260. https://doi.org/10.1016/j.ecole con.2007.02.024.

Cite this article as: Resque AGL, Piketty M-G, Coudel E, Messad S, Le Page C. 2021. Co-production of ecosystem services through agricultural practices: perception of stakeholders supporting smallholders in the Brazilian Amazon. Cah. Agric. $30: 20$. 